Japan. J. Med. Sci. Biol., 19, 73-84, 1966

\title{
SEROLOGIC RESPONSE OF ATOMIC BOMB SURVIVORS FOLLOWING ASIAN INFLUENZA VACCINATION
}

\author{
Masatsugu KANAMitsu,* Katsuhiko MORITA,* Stuart C. FINCH,** \\ Hiroo KATO*** AND SHIGEYUKI ONISHI*** \\ *Department of Hygiene, Sapporo Medical College \\ **Atomic Bomb Casualty Commission (ABCC) \\ ***Hiroshima, Nagasaki Branch Laboratory of National Institute of Health
}

(Received: December 11th, 1965)

\begin{abstract}
The effect of atomic bomb radiation on antibody production was studied among persons living in 1961 who were exposed while in-utero to the atomic bomb in either Hiroshima or Nagasaki. They were inoculated with an Asian infuenza virus vaccine. The relationship between the distance from the hypocenter at the time of the bombing and production of complement-fixing antibody to various types of influenza A virus was observed. The doctrine of original antigenic sin was applied to determine the effect. Patterns of the antibody levels in the group beyond $3,000 \mathrm{~m}$ suggested that the virus of primary infection in the survivors was type A1. Significantly reduced A1 type serum antibody levels were noted in both pre-and postvaccination sera of the subjects within $2,000 \mathrm{~m}$ from hypocenter in Nagasaki.

The effect of a previous radiation exposure appeared much more clearly in heterotypic antibody response following Asian influenza vaccination, that is, the antibody responses to type A1 viruses were almost completely suppressed in the subjects exposed within $1,600 \mathrm{~m}$ in both cities despite the fact that the antibody responses to type A viruses were similar to those in the group beyond $3,000 \mathrm{~m}$. In contrast, homotypic antibody response to Asian type virus was rather enhanced in the subjects proximal exposed.
\end{abstract}

\section{INTRODUCTION}

A number of studies have been conducted in animals to determine the effect of X-ray exposure on antibody production (Talmage, 1955; Hašek and Lengerová, 1960 ; Taliaferro et al., 1964). These studies have demonstrated that a maximum suppression of antibody production occurs when animals are irradiated shortly before administration of antigen, and that this suppression of antibody production persists for several weeks up to several months following irradiation.

In an analogous fashion, it is likely that antibody production in those persons exposed to excessive amounts of ionizing radiation from atomic detonation in Hiroshima and Nagasaki might have been transiently suppressed.

Studies have been conducted to determine the effects of radiation exposure on blood group antibody (Hollingsworth et al., 1960), blood bactericidal activity (Hollings-

金光正次・森田克彦（札幌医科大学衛生学教室）

Stuart C. Finch（原爆傷害調查委員会）

加藤寬夫 ・大西繁幸（国立予防衛生研究所広島・長崎支所） 
worth and Hamilton, 1960), and serum agglutinin titers following typhoid-paratyphoid vaccination (Shimizu et al., 1963) in the atomic bomb survivors of Hiroshima. No appreciable difference between serum antibody titers of the survivors and controls were found. It should be emphasized, however, that these studies were conducted more than 10 years after the atomic bombs. These recent failures to demonstrate residual impairment of antibody production in the heavily exposed are not in conflict with the current thought about immune suppression by radiation. It is likely that following these years antibody production mechanisms have been restored. It is also likely that the method usually employed for immunologic studies of this type may not detect previously damaged antibody production mechanisms.

Davenport and his collaborators have reported that the serum antibody levels which appeared in response to influenza virus infection in a specific age group were the highest against the strain of virus of the initial infection (Davenport, Hennesy and Francis, 1953 ; Davenport and Hennesy, 1956; Hennesy and Davenport, 1958). On the basis of the age specific patterns of antibody response to influenza viruses they established the doctrine of original antigenic sin (Francis, 1959). This phenomenon has been understood as being due to immunologic memory of type specific antigen of the virus of primary infection.

The principles of immunologic memory suggested a possible method for detecting the effects of previous radiation exposure on antibody production. The method is based on the assumption that immunologic memory of the virus of primary infection was more poorly established in the heavily exposed than in the unexposed subjects. Thus, following inoculation with influenza virus vaccine antigenically related to the virus of primary infection, lower levels of serum antibody against the primary virus should develop in the heavily exposed subjects in comparison to the nonexposed controls. This concept forms the basis for this study.

\section{MATERIALS AND MethodS}

Subjects: Persons living in 1961 who had been exposed to the atomic bomb (ATB) in either Hiroshima or Nagasaki while in-utero within $2,000 \mathrm{~m}$ from the hypocenter ATB constituted the experimental group. The control group was of a similar age and sex distribution but each person was located beyond $3,000 \mathrm{~m}$ ATB. It is believed that these people received negligible amounts of ionizing radiation (Arakawa, 1959).

The in-utero subjects were chosen from participants in the Study of Children Exposed In Utero (PE-86). In Hiroshima, the subjects were selected from those receiving a regularly scheduled medical examination at $\mathrm{ABCC}$, while in Nagasaki the studies were performed on junior and senior high school students who had registered previously at ABCC. The number of subjects included in this study is shown in Table 1. Four of the Nagasaki subjects in the proximal group were found to have been in an air-raid shelter and completely protected from the atomic radiation (Ishida and Beebe, 1959). Therefore, these persons were excluded from the study.

Vaccine: An essential component of the experimental design of this study is the knowledge of the prevalence of the various influenza virus strains in Japan. This information first became available around 1945 and now is quite complete. Since all subjects included in the present study were born between August, 1945 and May, 
1946 the periods of exposure to the various strains of influenza virus were very similar. Inactivated monovalent Asian influenza virus vaccine prepared from Adachi/2/57 strain was used in the study. Its potency was $322 \mathrm{CCA} / \mathrm{ml}$. All the Nagasaki subjects were inoculated subcutaneously with $1 \mathrm{ml}$ of the vaccine during January and February, 1962. The Hiroshima subjects were vaccinated during the period of December, 1961 to April, 1962. Serum samples were collected twice; just before the vaccination and 4 weeks thereafter.

Table 1. Composition of study groups.

\begin{tabular}{ccc}
\hline & \multicolumn{2}{c}{ Distance from hypocenter ATB } \\
\cline { 2 - 3 } City & $<2,000$ meters & $>3,000$ meters \\
\hline Hiroshima & 116 & 128 \\
Nagasaki & 35 & 40 \\
\hline Total & 151 & 168 \\
\hline
\end{tabular}

Antibody titration: On the basis of a previous finding that the Davenport's doctrine reflects more clearly on complement-fixing antibody than hemagglutinationinhibition antibody (Kanamitsu et al., 1962), serum antibody levels were determined by means of complement-fixation. The antigens consisted of five strains of influenza A virus. Those chosen were (1) PR8 and (2) Weiss strains of Type A virus, (3) FMI and (4) Gotoh strains of Type A1 virus, and (5) the Adachi $/ 2 / 57$ strain of Asian type virus. The Gotoh virus is a variant strain of the A1 type which was isolated during an influenza epidemic at the beginning of 1957. It subsequently was identified as the virus antigenically homologous to the A1/Dutch/56 strain.

The allantoic fluids of embryonated eggs inoculated with each virus strain were centrifuged for 30 minutes at $3,000 \mathrm{rpm}$. The supernatants then were centrifuged for 50 minutes at $28,000 \mathrm{rpm}$. The pellets thus obtained were resuspended in a phosphatesaline buffer and the suspensions were used as antigens.

The small volume complement-fixation method described by Lépine (1954) was used for the determination of serum antibody levels. The only modification consisted of an overnight period of incubation at $4 \mathrm{C}$. Antibody titration of both pre- and postvaccination sera from each subject was performed always at the same time. Tubes showing complete inhibition of hemolysis were read as positive. Antibody titers were expressed as the reciprocal of the initial dilution of serum showing inhibition. As expected, except for the Asian type, the postvaccination levels of serum antibody were low. Therefore, a full shift of the reaction pattern to higher titers in the postvaccination serum was read as a significant rise in serum antibody. Serum from the Hiroshima subjects was titrated for antibody to all 5 viruses. The titration to Gotoh virus, however, was omitted from the Nagasaki study because of the small size of the serum samples. Occasional serum samples from subjects of both cities were too small to permit antibody titration to all the viruses. Serological examinations were performed at the virus laboratory of the Department of Hygiene, Sapporo Medical College. 


\section{RESULTS}

\section{Antigenic Type of Influenza Virus of Initial Infection}

The first strain of influenza $A$ virus to which the subjects were exposed was inferred from a comparison of serum antibody levels to each virus strain in the control population. This group was composed of persons beyond $3,000 \mathrm{~m}$ from hypocenters ATB in both cities. The results are shown in Table 2. Before vaccination, antibody

Table 2. Pre- and Postvaccination antibody levels in control subjects, Hiroshima and Nagasaki

\begin{tabular}{|c|c|c|c|c|c|c|}
\hline \multirow{3}{*}{ Antibody } & \multicolumn{6}{|c|}{ City } \\
\hline & \multicolumn{3}{|c|}{ Hiroshima } & \multicolumn{3}{|c|}{ Nagasaki } \\
\hline & Number & Mode & Mean titer* & Number & Mode & Mean titer \\
\hline \multicolumn{7}{|l|}{ Prevac. } \\
\hline Adachi, Asian & 127 & 8 & 8.1 & 39 & 8 & 5.0 \\
\hline Goth, A1 & 120 & 8 & 12.8 & - & - & - \\
\hline $\mathrm{F} M 1, \mathrm{~A} 1$ & 126 & 16 & 12.7 & 40 & 16 & 11.4 \\
\hline Weiss, A & 127 & 8 & 7.0 & 36 & 8 & 4.2 \\
\hline $\mathrm{P} \mathrm{R} 8, \mathrm{~A}$ & 126 & 8 & 6.4 & 39 & 8 & 9.6 \\
\hline \multicolumn{7}{|l|}{ Postvac. } \\
\hline Adachi, Asian & 127 & 32 & 43.6 & 39 & 64 & 50.1 \\
\hline Gotoh, A1 & 120 & 16 & 14.9 & - & - & - \\
\hline $\mathrm{F} M 1, \mathrm{~A} 1$ & 126 & 16 & 13.0 & 40 & 16 & 15.0 \\
\hline Weiss, A & 127 & 8 & 8.8 & 36 & 8 & 8.0 \\
\hline $\mathrm{P} \mathrm{R} 8, \mathrm{~A}$ & 126 & 8 & 10.1 & 39 & 16 & 15.3 \\
\hline
\end{tabular}

* Geometric mean.

levels to the type A1 viruses were markedly higher than to those of any other virus type. After vaccination, except for the expected high levels of Asian antibody, levels to type A1 viruses were the highest. The next highest levels were those to the PR8 virus strain, and the lowest levels were to Weiss virus, although the levels of PR8 antibody were almost identical to those of FM1 antibody in the Nagasaki group. These results suggest that the influenza virus of primary infection in these subjects was type A1.

\section{The Effect of Previous Radiation Exposure on Serum Antibody Levels}

The serum antiboby levels to individual virus strains in the subjects exposed within $2,000 \mathrm{~m}$ were compared to the serum antibody levels of the controls. In the Hiroshima subjects there was no apparent ralationship between the exposure distance and the serum antibody levels to any virus strain. The only possible exception was that the postvaccination levels to Asian virus were higher in the proximal group. In 
contrast, a relationship between the distance and serum antibody levels in both preand postvaccination serum samples from the Nagasaki subjects was observed. The results are shown in Fig. 1. The pre- and postvaccination serum levels of FM1 antibody were markedly lower in the exposed group than in the controls. The differences in antibody distribution between the groups are statististically significant at the $5 \%$ level by $\mathrm{X}^{2}$ test in each instance. Prevaccinotion levels of Weiss antibody also were lower in the proximal group though the differences in antibody distribution between the groups were not statistically significant. No such relationship was noted with the serum antibody levels to PR8 virus.

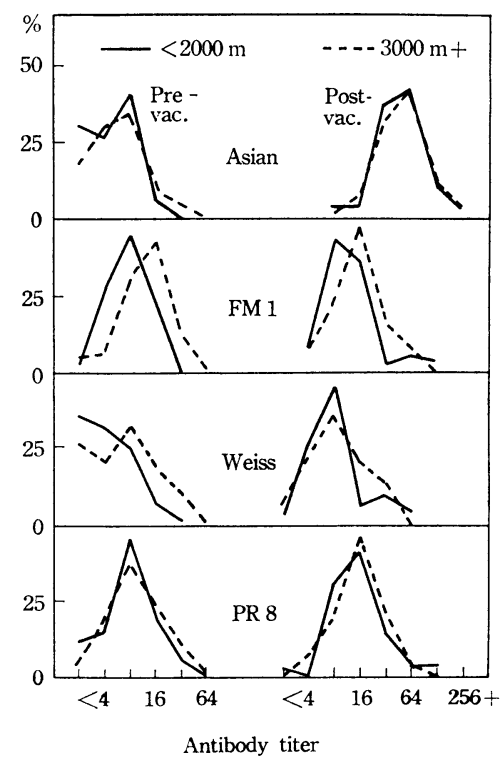

Fig. 1, Antibody levels in the in-utero subjects of Nagasaki by exposure distance.

\section{Factors Which Influence Antibody Response Other Than Previous Radiation Exposure}

Factors which may influence antibody response following vaccination besides the previous radiation exposure are: 1) initial antibody levels of subjects for whom elevation of antibody is to be studied, and 2) magnitude of rise in Asain antiboby homologous in type to the vaccine chosen for inoculation. Subjects of control groups of both cities were pooled and used for the study. The relationship between the initial levels of serum antibody and subsequent responses is shown in Fig. 2A. At least a 2 -fold rise in Asian antibody titer invariably occurred in those subjects with initial levels of $1: 8$ or lower. Appreciable rise in serum level of antibody to other viruses occurred less frequently even if the initial serum antibody level for a particular virus was low.

If the initial Asian type serum antibody level was 1:128 or greater there invariably was no significant response in Asian type serum antibody level following vaccination. The critical level was 1:32 for the other 4 viruses. This indicates that those subjects 
with initial serum antibody levels higher than these critical titers are of no value for the study of antibody response to the virus. The relationship between the magnitude of Asian antibody increase and the elevation of other types of serum antibodies is shown in Fig. 2B. All of the subjects without increases in their Asian antibody titers failed to demonstrate a rise in the serum level of other types of antibodies. Except for the Gotoh antibody, the frequency with which these heterotypic antibody levels increase was related to the magnitude of the rise in Asian antibody titer. It became apparent, therefore, that elevation of $\mathrm{A}$ and $\mathrm{A} 1$ type antibodies induced by Asian influenza vaccination was greatly influenced by these various sero-immunologic conditions of subjects. The results further indicate that the subjects to be used for the study on the effect of radiation on antibody response should be comparable in respect to sero-immunologic conditions.

A

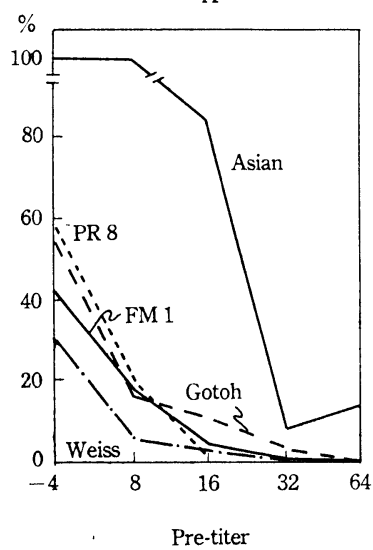

B

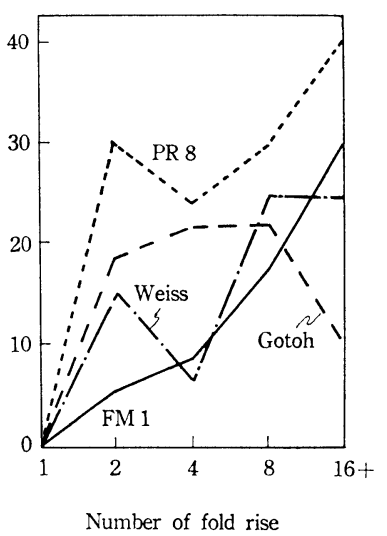

Fig. 2. Homo-and heterotypic antibody response in relation to prevaccination levels of the antibody and magnitude of increase in Asian antibody, control group.

\section{The Effect of Previous Radiation Exposure on Heterotypic Antibody Response}

The in Utero Study subjects of each city were divided according to the distance from the hypocenters ATB into three groups: one composed of those exposed within $1,600 \mathrm{~m}$, the second included those exposed between $1,600-1,999 \mathrm{~m}$, and the third group consisted of those located beyond $3,000 \mathrm{~m}$. Those subjects with initial serum antibody levels higher than the critical titer to which no antibody response occurred previously and those without any rise in Asian antibody were excluded. The frequency with which the subjects in each group showed a significant rise in serum antibody to $\mathrm{A}$ and A1 type viruses was compared. The results are shown in Table 3 . In the Hiroshima subjects, initial serum antibody levels to the same viruses are comparable among all groups while the magnitude of rise in Asian antibody is greatest in the middle distance group. Therefore, both the first group $(<1,600 \mathrm{~m})$ and the third group $(>3,000 \mathrm{~m})$ are suitable for the study of antibody responses to A and A1 type viruses. In the first group there was a moderate reduction in the frequency of serum antibody rise of the Gotoh type. A much more marked reduction of frequency of rise 
Table 3. Heterotypic antibody response in the in-utero subjects by exposure distance following Asian influenza vaccination

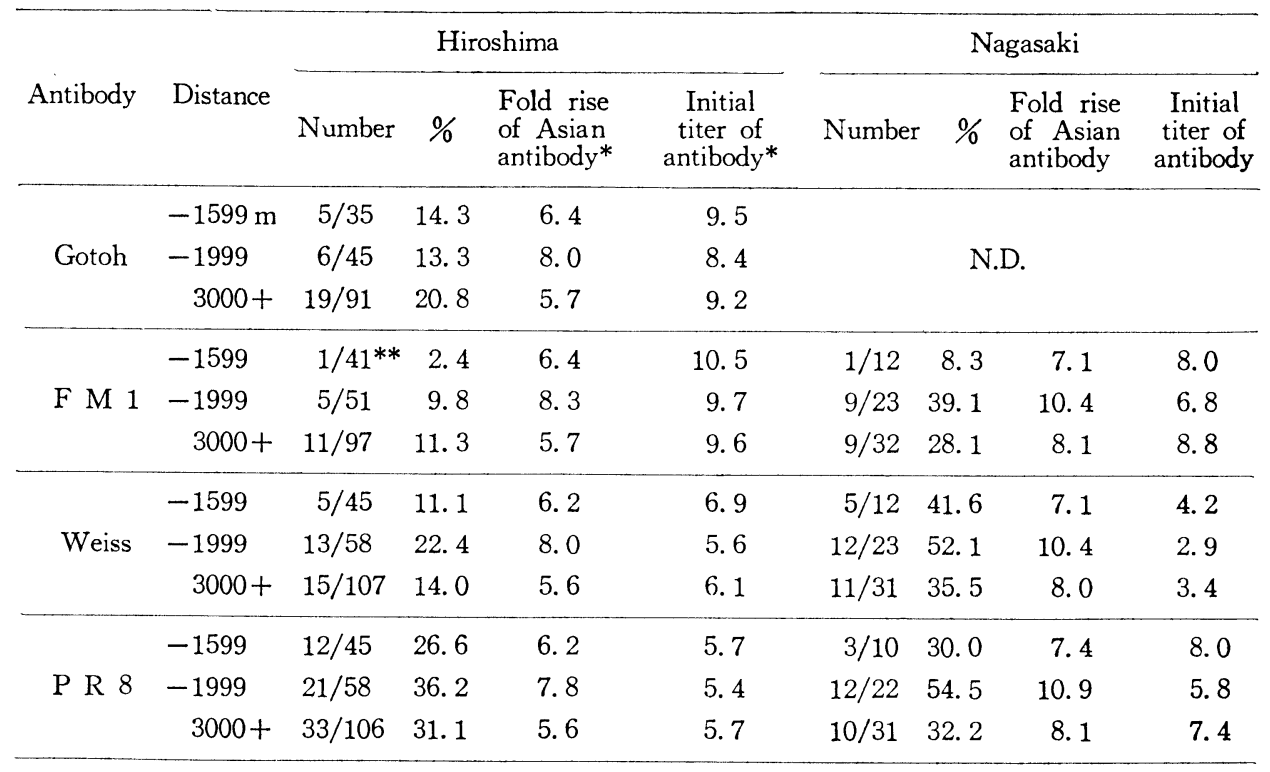

The denominator indicates the number of subjects and the numerator that of those with at least 2 fold rise in the antibody.

* Geometric means. ** Included the one who elevated the antibody in the group without rise in Asian titer.

in FMl type serum antibody, however, was noted in the subjects in this group. The frequency of rise in serum antibody levels to A type viruses was approximately the same in both the groups.

In the Nagasaki subjects, the magnitude of rise in Asian serum antibody levels was remarkably greater in the middle distance group $(1,600-1,999 \mathrm{~m})$ in comparison to the other 2 groups which showed a similar change. Therefore, the middle distance group should be excluded from the study. The most striking finding was the reduced frequency with which subjects in the first group $(<1,600 \mathrm{~m})$ developed a rise in serum antibody to FMl virus. The response for the other virus strains was comparable for all groups.

Since the antibody response patterns for the subjects of both cities were similar, the results for each group were pooled. Each group then was subdivided into a group of persons who showed a 2 to 4 -fold rise in serum antiboby to Asian virus and a second group composed of subjects with an 8 -fold or greater response to this virus. The number of subjects in each distance group ranged from 14 to 80 . The frequency with which the subjects in each group demonstrated an elevation of serum antibody levels to $\mathrm{A}$ and $\mathrm{A} 1$ type viruses is shown in Fig. 3. Prevaccination serum antibody levels to same virus in the three distance groups with same magnitude of Asian antibody increase are comparable. None of the 23 most proximally exposed subjects with lower increases in Asian serum antibody showed a significant rise in Gotoh serum antibody. One of the 14 subjects in the middle distance group and 10 of 47 subjects 
in the group beyond $3,000 \mathrm{~m}$ developed significantly elevated Gotoh serum antibody levels. The results of the most proximal group in comparison to the more distal group were statistically significant at the $5 \%$ level by the one-tailed test. Elevation of FM1 serum antibody levels was markedly reduced in the most proximal group with the greater elevation of Asian serum antibody, that is, only one of 29 subjects in the most proximal group showed a rise in FM1 serum antibody, while 14 of 56 subjects in the middle distance group and 16 of 77 subjects in the group beyond $3,000 \mathrm{~m}$ developed an elevation of the antibody levels. The reduction of frequency of FM1 serum antibody response in the most proximal group was statistically significant at the $5 \%$ level by the one-tailed test. The frequency of serum antibody elevation to the Weiss virus also appeared to be reduced in the most proximal group with lower increases in Asian serum antibody although the reduction was not statistically significant. No such relationship was noted with PR8 antibody. It is noted, however, that the frequency of serum antibody response to PR8 virus is generally greater than that to the other virus strains.

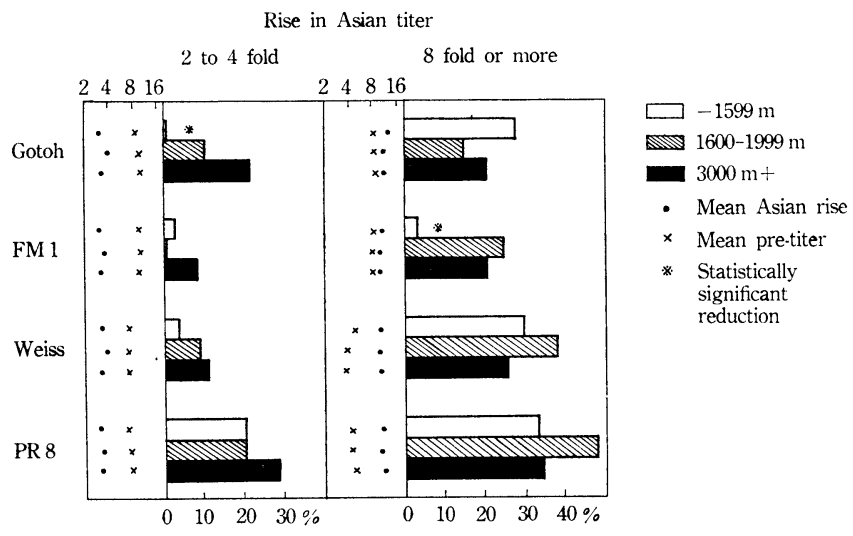

Fig. 3. Heterotypic antibody response by exposure distance following Asian influenza vaccination.

\section{The Effect of Previous Radiation Exposure on Homotypic Antibody Response}

Homotypic response of Asian serum antibody following vaccination was remarkable. Therefore, the distance from hypocenters ATB was related to the magnitude of rise in the antibody for the subjects. The subjects located at comparable distances from hypocenters ATB in both cities were pooled, then subclassified into 3 groups depending upon the initial Asian serum antibody level. The first group had serum levels of $1: 4$ or lower, levels in the second group were $1: 8$ to $1: 16$, and those with the levels of $1: 32$ to $1: 64$ made up the third group. The number of subjects in each subgroup was 100,184 , and 29 , respectively. The number of subjects within $2,000 \mathrm{~m}$ and those beyond $3,000 \mathrm{~m}$ in each subgroup was roughly the same. The relationship between exposure distance and the magnitude of rise in Asian serum antibody levels is shown in Fig. 4. The tendecy that the lower the initial level of the serum antibody the greater the magnitude of the increase, is apparent in the figure. Surprisingly, 
elevation of Asian serum antibody was considerably higher in the subjects of the exposed group, irrespective of initial antibody level. The general results were unchanged even when the results for each city were considered separately.

Study was further conducted for the In Utero Study subjects to determine the effect of month of gestation ATB on antibody production, but no appreciable result was obtained.

\section{Discussion}

The highest prevaccination serum antibody levels in the control subjects were against the A1 type viruses. This was an unexpected finding since type A influenza virus, especially the Weiss strain, first appeared in 1943 and possibly remained through 1948 (Fukumi et al., 1951).

Although the in-utero subjects may have been exposed to the Weiss type virus from 3-4 years, there is evidence that the first virus of importance to the antibody forming mechanisms was of the A1 type. The reasons for this assumption are as follows :

1) Type A1 virus was identified as early as 1946 in Australia. It probably was brought to Japan in that same year by the Australian troops.

2) During the first 3-6 months of life there is little or no antibody response to antigenic stimulation.

3) Several years may pass before a newborn population is infected with a specific virus and saturated with serum antibody to the virus (Lief and Henle, 1960). The total contact period for A1 type virus was about 10 years. Therefore, it is reasonable to assume that A1 type virus probably was the virus of primary infection for virtually all of those studied. The serum antibody levels in the control subjects were consistent with this assumption.

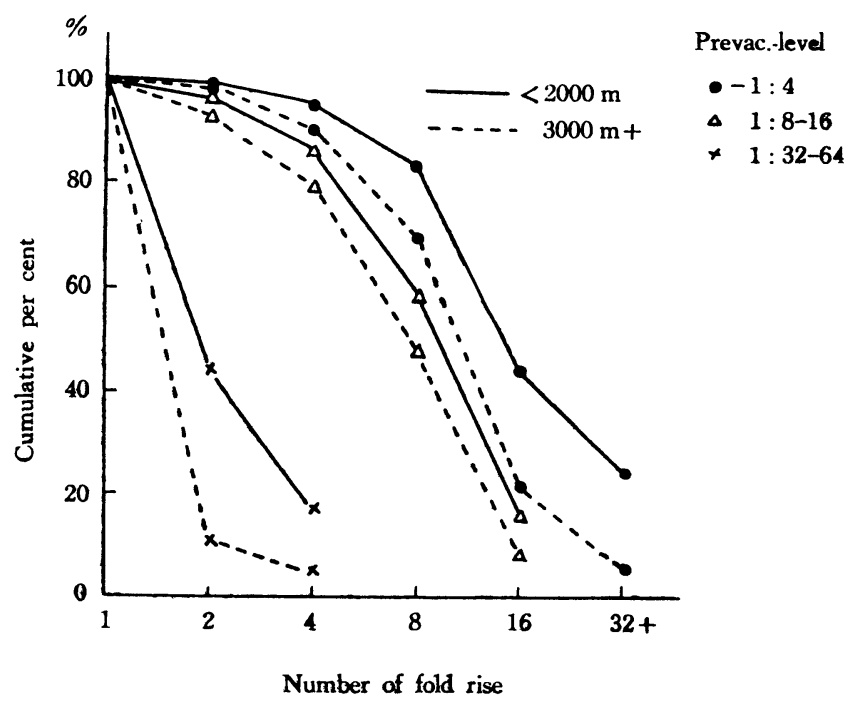

Fig. 4. Relationship between exposure distance and homotypic response of Asian antibody following vaccination. 
The reduced serum antibody levels to FM1 virus in the Nagasaki subjects possibly may have been the result of previous radiation exposure. A similar result was not obtained in Hiroshima, however. Perhaps differences in each city in the amounts of energy released as neutrons and gamma rays from the atomic bombs may have been a factor (Arakawa, 1959). Variations in topography and other unknown factors also may have influenced irradiation dose. If previous radiation exposure had damaged antibody producing mechanisms, however, it was thought that evidence of this damage might still be detectable in a more convincing fashion.

The heterotypic antibody response of the exposed subjects to Asian influenza vaccination more clearly demonstrated a possible radiation effect. In comparison to their controls, the proximal exposed subjects of both cities showed considerably poorer type FM1 serum antibody responses. In Hiroshima, the subjects in this group also failed to increase their serum antibody levels to Gotoh virus which is a variant strain of type A1 virus. These data suggest that there may have been residual radiation damage to the antibody forming mechanisms of the children in the proximal group at the time of their primary A1 virus infections. Years later the poor antibody response of the same type in these subjects may still be evidence of this early radiation effect.

The heterotypic serum antibody responses to the type $\mathrm{A}$ influenza viruses is somewhat confusing. Both the control and the heavily exposed subjects showed the greatest frequency of response to the PR8 virus. On the other hand, the rise in serum antibody to Weiss type virus was extremely poor for both groups. The reason for this apparent descrepancy is unclear but there is evidence that both the Asian and prototype A viruses may have partially common antigens (Kanamitsu et al., 1962 ; Schulman and Kilbourne, 1965). The overall development of serum antibody to the Asian virus following vaccination was somewhat better in the proximal exposed subjects than it was in their controls. This result may have been spurious and difficultly elucidated. Although there may have been overcompensation of antibody production following radiation-induced depression (Taliaferro et al., 1964), it is possible, but unlikely, that overcompensation of such long duration could persist.

The maximum duration of suppression of antibody production in irradiated animals is stated to be in the range of 8 weeks (Taliaferro 1958). Radiation-induced suppression of an anamnestic antibody response, however, pressumably may be of longer duration (Claman, 1963). The poor production of FM1 and Gotoh serum antibodies in the heavily exposed subjects suggests that radiation-impaired antibody synthesis of this particular type may have persisted about 10 years. This duration is considerably longer than that noted in animal studies. Two possible explanations are offered. One is that suppression of antibody synthesis actually persisted for this long period of time in the in-utero exposed. The fact that the fetus is highly sensitive to ionizing radiation may support this explanation. It is possible that impairment of antibody production was more severe and lasted longer in the persons exposed during fetal life than those exposed in postnatal life. Previous experimental studies have almost invariably been conducted in postnatally irradiated animals. Another possible explanation is that the in-utero exposed subjects might have become immunologically tolerant to the influenza virus of primary contact. Persistence of antigen in vivo is said to be an indispensable factor for tolerance to develop. Persistence of influenza virus in the lungs of mice with radiation-induced depression of antibody synthesis have been reported (Beutler and 
Gezon, 1952; Quilligan et al., 1963 ; Berlin, 1965). The results may support the concept that irradiated animals become partially tolerant to the influenza virus. Since the appearance of type $\mathrm{A} 1$ influenza virus in Japan, epidemics due to this type virus frequently occurred. These circumstances may favor a persistent type A1 influenza virus infection in the heavily exposed in-utero subjects. Reasons for the inordinately long duration of impaired antibody production in the heavily irradiated in-utero subjects are, however, a subject for future investigation.

The authors are deeply indepted to Dr. Ogonuki, the Director of the Chiba Prefecture Serum Institute and Dr. Fukumi, the Chief of the Department of Bacteriology, National Institute of Health for preparation and potency test of the Asian influenza vaccine used for the present study.

\section{REFERENCES}

ARAKAWA, E. T. (1959): Radiation dosimetry in Hiroshima and Nagasaki atomic bomb survivors. ABCC Tech. Rep. Ser. No. 14, 1-17.

BERLIN, B. S. (1965): Sparing effect of X-rays for mice inoculated intranasally with egg-adapted influenza virus, CAM strain. Proc. Soc. Exptl. Biol. Med., 117, 864-869.

Beutler, E. And Gezon, H. M. (1952): The effect of total body X-irradiation on the susceptibility of mice to influenza A virus infection. J. Immunol., 68, 227-242.

Claman, H. N. (1963) : Decline of antibody and impaired anamnesis following X-ray. J. Immunol., 91, 29-38.

Davenport, F. M., Hennesy, A. V. And Francis, T. Jr. (1953) : Epidemiologic and immunologic significance of age distribution of antibody to antigenic variants of influenza virus. J. Exptl. Med., 98, 641-656.

DAVEPorT, F. M. AND HENNEsy, A. V. (1956): A serologic recapitulation of past experience with influenza A: antibody response to monovalent vaccine. J. Exptl. Med., 104, 85-97.

Francis, T. Jr. (1959) : Influenza. In River's Viral and Rickettsial Infections of Man. 3 rd Ed. Lippincott. 633.

Fukumi, H., Nishikawa, F., Kitayama, T. AND Sunagawa, S. (1951): Change in antigenic type of influenza virus in Japan. NIHON IJI SHIMPŌ, No. 1443, 6-10 (In Japanese).

HAŠEK, M. AND LENGEROVÁ, A. (1960) : Immunology. In ERRERA's Mechanisms in Radiobiology. Acad. Press. 2, 207-229.

Hennesy, A. V. AND Davenport, F. M. (1958) : Epidemiologic implications of the distribution by age of antibody response to experimental influenza virus vaccines. J.. Immunol., 80, 114-121.

Hollingsworth, J. W., Hamilton, H. B., Beebe, G. W. And Yamasaki, M. (1960) : Blood group antibody levels in Hiroshima. ABCC Tech. Rep. Ser., No. 08, 1-19.

Hollingsworth, J. W. AND Hamilton, H. B. (1960): Blood bactericidal activity in Hiroshima subjects. ABCC Tech. Rep. Ser., No. 14, 1-15.

IshidA, M. AND BEeBE, G. W. (1959): Research plan for joint NIH-ABCC study of life-span of A-bomb survivors. ABCC Tech. Rep. Ser., No. 04, 1-89.

Kanamitsu. M., Gotoh, H., Morita, K., Nagao, M., Taira, T., Finch, S. C., Katoo, H. AND ONISHI, S. (1962): Study on the doctrine of original antigenic sin and its application for examination of the effect of atomic bomb radiation on antibody production. Rep. 10th Nat. Congr. Jap. Viol. Soc., 69-70 (In Japanese).

KANAMITSU, M. (1962): Epidemiological consideration on influenza. SOGO IGAKU. 19, 219-222 (In Japanese).

LÉPine, P. (1954): Influenza. A review of current research. W. H. O. Monograph Ser., No. 20, $87-124$. 
LIEF, F. S. AND HENLE, W. (1960): Antigenic analysis of influenza viruses by complementfixation. VI. Implications of age distribution of antibodies to heterologous strains following infection and vaccination. J. Immunol., 85, 494-510.

Quilligan, J. J., Boche, R. D., Carruthers, E. J., Axtell, S. L. ANd Trivedi, J. C. (1963): Continuous cobalt-60 irradiation and immunity to influenza virus. J. Immunol., 90, 506-511.

Schulman, J. L. AND Kilbourne, E. D. (1965): Induction of partial speific heterotypic immunity in mice by a single infection with influenza A virus. J. Bacteriol., 89, 170-174.

Shimizu, K., Watanabe, M., ItoH, S., Yamamoto, S. And Tsukada, S. (1963): Antibody and complement values among A-bomb survivors in Hiroshima. I. A statistical study. HIROSHIMA IGAKU, 19, 477-483 (In Japanese).

TAliaferro, W. H., Taliaferro, L. G. AND Jaroslow, B. N. (1964): Radiation and Immune Mechanisms. Acad. Press.

TAliAfERRO, W. H. (1958): Modification of the immune response by radiation and cortisone. Ann. N. Y. Acad. Sci., 69, 745-764.

TAlmaGe, D. W. (1955): Effect of ionizing radiation on resistance and infection. Ann. Rev. Microbiol., 9, 335-346. 